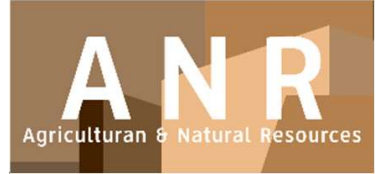

PAPER - OPEN ACCESS

Potensi Pemanfaatan Limbah Air Pendaurulangan Papan Partikel Sebagai Pupuk Cair Bibit Tanaman Kehutanan Lambat Tumbuh (Slow Growing Species)

$\begin{array}{ll}\text { Author } & : \text { Arif Nuryawan dkk., } \\ \text { DOI } & : 10.32734 / \text { anr.v3i1.834 } \\ \text { Electronic ISSN } & : 2654-7023 \\ \text { Print ISSN } & : 2654-7015\end{array}$

Volume 3 Issue 1-2020 TALENTA Conference Series: Agriculturan \& Natural Resource (ANR)

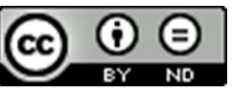

This work is licensed under a Creative Commons Attribution-NoDerivatives 4.0 International License.

Published under licence by TALENTA Publisher, Universitas Sumatera Utara

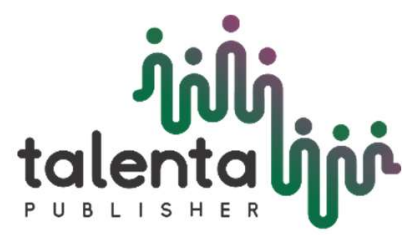




\section{Potensi Pemanfaatan Limbah Air Pendaurulangan Papan Partikel Sebagai Pupuk Cair Bibit Tanaman Kehutanan Lambat Tumbuh (Slow Growing Species)}

\author{
Arif Nuryawana, Putri Azizah Annur Manik ${ }^{a}$, Aulia Ul Husna ${ }^{a}$, Kansih Sri Hartinia \\ ${ }^{a}$ Fakultas Kehutanan, Universitas Sumatera Utara, Jl. Tri Dharma Ujung No. 1 Kampus USU Medan, Sumatera Utara, Indonesia 20155 \\ arif5@usu.ac.id
}

\begin{abstract}
Abstrak
Untuk menganalisis potensi limbah air hasil pendaurulangan papan partikel komersial berperekat urea-formaldehida (UF) untuk digunakan sebagai pupuk cair tanaman kehutanan lambat tumbuh (slow growing species) dilakukan pengujian PSA (particle size analyzer) berskala mikron pada limbah air tersebut dan perhitungan fraksi sol dari film UF. Pengukuran PSA menggunakan Malvern Mastersizer 3000 Hydro EV dan penghitungan fraksi sol menggunakan metode gravimetri. Hasil yang diperoleh terdapat dominasi partikel kayu pada limbah air tersebut yang berukuran 20 hingga $50 \mu \mathrm{m}$ sebanyak $(31,78 \pm 5,19) \%$. Analisis film UF menunjukkan terdapat fraksi sol sebesar $(22.24 \pm 2.51) \%$ untuk penggunaan hardener ammonium chloride $\left(\mathrm{NH}_{4} \mathrm{Cl}\right)$ sebanyak $1 \%$ dan $(4.73 \pm 2.25) \%$ untuk penggunaan hardener $\mathrm{NH}_{4} \mathrm{Cl}$ sebanyak $3 \%$. Hal ini mengindikasikan limbah air hasil pendaurulangan papan partikel komersial tersebut berpotensi dapat digunakan sebagai pupuk cair karena mengandung bahan organik berupa partikel kayu berukuran mikro dan fraksi sol yang berasal dari perekat UF sehingga dapat digunakan sebagai sumber nutrisi tanaman kehutanan lambat tumbuh (slow growing species).
\end{abstract}

Kata Kunci: daur ulang, limbah air, urea-formaldehida (UF), partikel kayu, fraksi sol

\section{Pendahuluan}

Pada penelitian sebelumnya, aplikasi limbah air hasil pendaurulangan papan partikel produksi skala laboratorium yang direkat dengan urea-formaldehida (UF) beremisi rendah dengan kadar nitrogen (N) yang bervariasi nilainya sebagai pupuk cair untuk bibit tanaman kehutanan hanya memberikan respon positif untuk jenis cepat tumbuh jabon (Anthocephalus cadamba) namun tidak untuk jenis lambat tumbuh seperti mahoni (Swietenia mahagony) [1]. Analisis lanjut pada parameter pertumbuhan bibit A. cadamba selama tiga bulan atau $12 \mathrm{mst}$ (minggu setelah tanam) menunjukkan tinggi dan diameter bibit mengalami pertumbuhan yang signifikan setelah diberi pupuk cair tersebut, namun tidak berpengaruh pada nilai biomassa tajuk dan akar [2].

Penelitian lanjutan untuk hal ini masih dan sangat perlu dilaksanakan seperti aplikasinya untuk jenis-jenis bibit lambat tumbuh yang lain (dapat dicoba pada bibit ki hujan (Samanea saman), ingul (Toona sureni), dan gaharu (Aqualaria malaccensis) mengingat setiap spesies tentu memiliki sifat-sifat yang spesifik pula). Demikian juga karena merupakan spesies yang lambat tumbuh, durasi pengamatan terhadap parameter pertumbuhan dapat dibuat dan dipertimbangkan menjadi lebih panjang (misalnya enam bulan). Dosis pemberian pupuk cair terhadap bibit juga perlu diperhitungkan sehingga nutrisi yang terkandung dalam pupuk cair tersebut mencukupi untuk pertumbuhan bibit.

Pada studi ini diteliti kandungan limbah air hasil pendaurulangan papan partikel komersial yang digunakan sebagai pupuk cair meliputi partikel kayu sisa pendaurulangan yang terdispersi dalam pupuk cair tersebut dan kandungan 
fraksi sol yang berasal dari perekat UF yang digunakan untuk membuat papan partikel komersial tersebut. Fraksi sol merupakan bagian yang tidak habis bereaksi saat pembuatan perekat UF dan tidak cured/ matang saat diaplikasikan pada saat pembuatan / produksi papan partikel [3].

\section{Metode Penelitian}

\subsection{Bahan}

Bahan utama yang digunakan adalah papan partikel komersil produksi industri PT. Canang Indah, Belawan, Medan yang direkat dengan UF (Gambar 1). Simulasi pembuatan film dengan menggunakan perekat UF dan hardener ammonium chloride $\left(\mathrm{NH}_{4} \mathrm{Cl}\right)$ diperoleh dari industri yang sama.

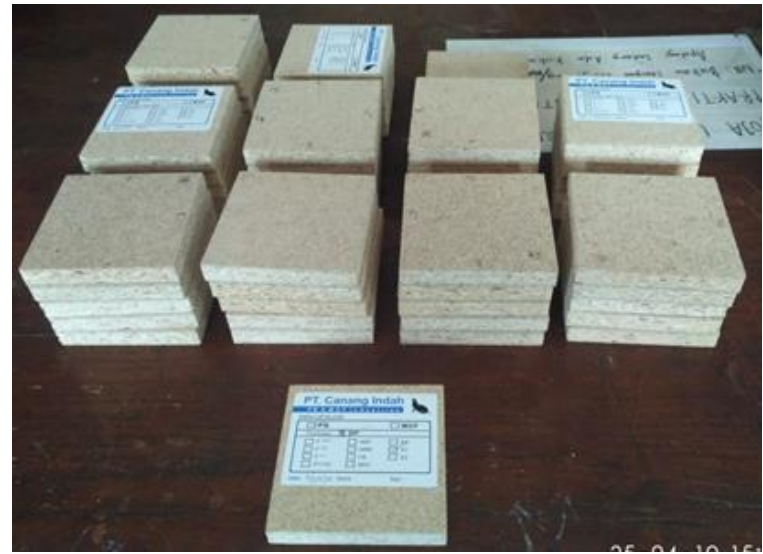

(a)

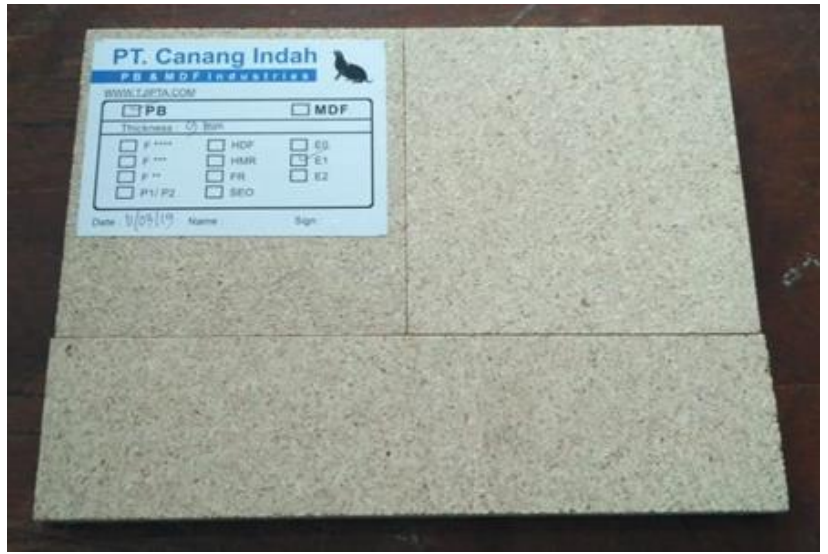

(b)

Gambar 1. Sampel papan partikel dari PT.Canang Indah, Belawan, Medan (a) Insert (b)

\subsection{Persiapan contoh uji dan analisis kandungan partikel kayu yang terdispersi dalam pupuk cair}

Metode untuk memperoleh pupuk cair adalah dengan merendam contoh uji (CU) papan partikel dalam bak air pada suhu ruang selama 12 hingga 16 hari perendaman disertai tindakan mekanis seperti mengaduk dengan stick/ tongkat hingga CU papan partikel tersebut hancur. Prosedur ini mengacu pada studi yang dilakukan oleh [1] dalam merendam papan partikel komersial hingga rusak terjadi pada siklis ke-6 hingga siklis ke-8, di mana satu siklis merupakan kegiatan merendam selama 24 jam-meniriskan-mengeringkan dengan mengoven selama 24 jam dan merendamnya kembali yang menghabiskan waktu total $2 \times 24$ jam atau 2 hari. Setelah papan partikel tersebut rusak/hancur, yang ditandai dengan terpisahnya partikel-partikel penyusun papan partikel, residu padat yang berupa partikel-partikel kayu disaring dengan kain blacu sehingga terpisah antara residu padat dengan airnya. Residu padat akan dikeringkan dengan dijemur dan dioven dan akan digunakan kembali sebagai bahan baku papan partikel kembali sedangkan limbah air dipisahkan dalam suatu wadah tertutup untuk digunakan sebagai pupuk cair.

Analisis kandungan partikel kayu yang terdispersi dalam pupuk cair tersebut dilakukan menggunakan particle size analyzer (PSA) Malvern Mastersizer 3000 Hydro EV berskala mikron dengan dua kali ulangan secara duplo. Hasil analisis ditabulasikan dan diklasifikasikan menurut kelas diameter.

\subsection{Persiapan $C U$ dan Perhitungan fraksi sol yang tedapat dalam film UF}

Untuk mengukur kandungan fraksi sol (bagian yang tidak ikut berikatan silang pada rantai polimer perekat UF, sehingga bisa diekstrak atau terlarut) yang digunakan sebagai lem pada papan partikel ini, perlu dibuat CU lapisan tipis/film dari perekat UF sebagai simulasinya. Film ini dibuat mengikuti prosedur [4], yaitu dengan mencampurkan resin UF dengan hardener ammonium choride $\left(\mathrm{NH}_{4} \mathrm{Cl}\right)$ sebanyak 1 dan $3 \%$ berdasarkan berat solid resin UF kemudian dioven pada suhu $50^{\circ} \mathrm{C}$ selama $24 \mathrm{jam}$. Film dibuat tiga ulangan untuk masing-masing jumlah hardener dan dievaluasi 
nilai pengembangannya sehingga bisa diukur secara gravimetrik. Pengembangan dimaksudkan untuk mengembangkan ikatan silang rantai polimer perekat UF sehingga fraksi sol yang terperangkap di sela-sela ikatan silang bisa terlepas dan bisa diukur jumlahnya.

Pengembangan dilakukan selama periode 24 jam menggunakan dimetil sulfoksida (DMSO) sebagai pelarut athermal untuk menghindari hidrolisis CU film. CU direndam dalam botol dengan $3 \mathrm{ml}$ DMSO, dan botol tersebut direndam dalam bak air pada suhu $60^{\circ} \mathrm{C}$. Sebelum perendaman, semua CU ditimbang untuk massa awal (mo) dengan timbangan analitik. Setelah 24 jam dan massa CU film mengembang diperoleh, CU tersebut segera dikeluarkan dengan hati-hati dari dalam botol dengan menggunakan pinset. CU film ditiriskan di atas kertas tisu sehingga $\mathrm{CU}$ tersebut bebas dari DMSO. Untuk memastikan tidak ada lagi DMSO yang masih melekat, CU film diangin-anginkan dalam fume-hood (ruang asam) pada suhu ruang selama 24 jam. Setelah itu massa kering CU film tersebut ( $m$ dry) ditentukan. Fraksi sol $\left(\omega_{\text {sol }}\right)$ dapat dihitung dengan persamaan (1) berikut

$$
\omega \operatorname{\omega sol}(\%)=\frac{m d r y-m o}{m o} \times 100 \%
$$

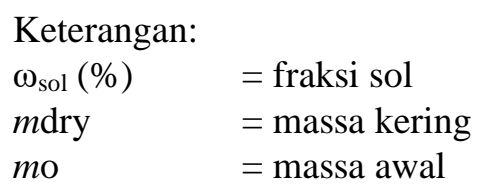

Hasil perhitungan dirata-ratakan untuk tiap jumlah hardener dan hasilnya ditabulasikan. Adanya fraksi sol mengindikasikan adanya massa terlarut yang berasal dari perekat UF yang tidak ikut berikatan silang (cross-link) yang dapat digunakan sebagai sumber nutrisi bibit.

\section{Hasil dan Pembahasan}

\subsection{Hasil Analisis Partikel Kayu yang Terdispersi}

Pupuk cair yang berasal dari limbah pendaurulangan papan partikel terlihat berwarna kuning keruh, menandakan adanya material leaching (tercuci) dari bahan penyusun papan partikel yang kemudian terlarut atau terdispersi. Berdasarkan hasil pengukuran konsentrasi dengan PSA diperoleh nilai rataan konsentrasi pupuk cair tersebut adalah $(0,0082 \pm 0,0012) \%$.

Hasil analisis pupuk cair yang berasal dari limbah air hasil pendaurulangan papan partikel komersial PT.Canang Indah, Medan menunjukkan dominansi tiga besar partikel kayu yang terdispersi berturut-turut pada kelas diameter 20$50 \mu \mathrm{m}$ sebanyak $(31,78 \pm 5,19) \%$; kelas diameter $10-20 \mu \mathrm{m}$ sebanyak $(20,46 \pm 4,31) \%$; dan kelas diameter 50-100 $\mu \mathrm{m}$ sebanyak $(15,74 \pm 3,26) \%$ serta dijumpai partikel kayu yang berukuran $>200 \mu \mathrm{m}$ sebanyak $2,8 \%$ seperti yang tersaji pada Gambar 2.

Partikel kayu yang terdispersi dalam pupuk cair tersebut dapat menjadi sumber nutrisi bagi bibit tanaman karena kayu tersusun atas sebagian besar bahan organik (yang terdiri atas karbon $(\mathrm{C})$, hidrogen $(\mathrm{H})$, dan oksigen $(\mathrm{O})$ ) dan sebagian kecil bahan anorganik (mineral) dan keduanya dalam bentuk senyawa yang memiliki berat molekul rendah [5]. 


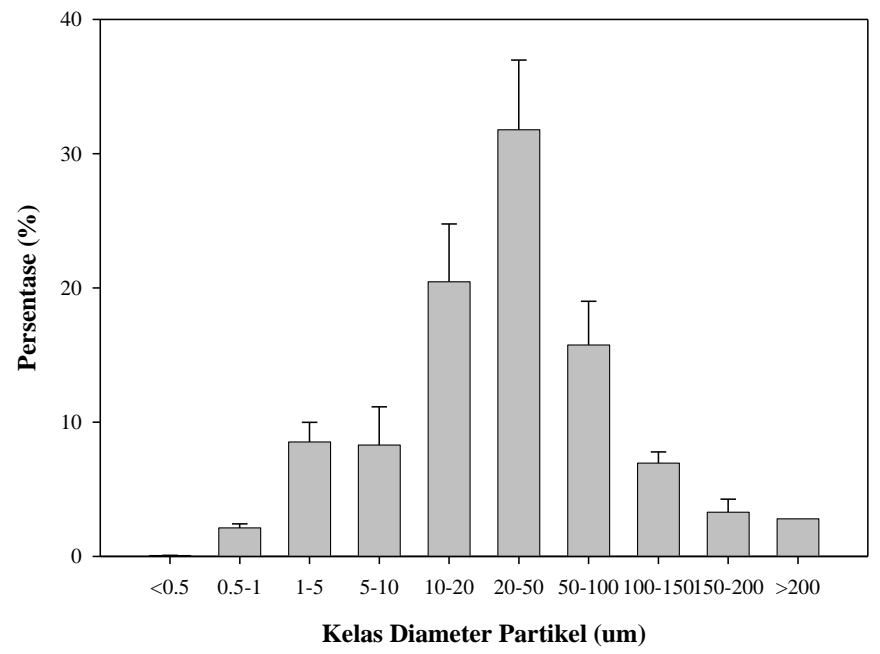

Gambar 2. Hasil analisis pengkelasan diameter pada air limbah pendaurulangan papan partikel komersil produksi PT.Canang Indah, Medan.

Selanjutnya kelompok bahan organik ini akan mengalami reaksi redoks (reduksi-oksidasi) karena memiliki karakteristik biokimia dan fungsi fisiologis [6] dan diserap tanaman dalam bentuk ion seperti $\mathrm{HCO}_{3}{ }^{-}, \mathrm{NO}_{3}{ }^{-}, \mathrm{NH}_{4}{ }^{+}$, atau $\mathrm{SO}_{4}{ }^{2-}$ sehingga menjadi elemen penyusun asam amino, protein, enzim, dan asam nukleat sebagai bahan pembentuk sel hidup [7]. Sementara bahan anorganik yang berupa mineral dalam bentuk abu sudah dikenal sejak lama sebagai alternatif pupuk [8] karena kandungannya. Elemen utama yang terdapat di dalam kayu dan dibutuhkan oleh tanaman sebagai mikro-nutrisi adalah kalsium $(\mathrm{Ca})$, kalium $(\mathrm{K})$, magnesium $(\mathrm{Mg})$, alumunium $(\mathrm{Al})$, besi $(\mathrm{Fe})$, dan pospor $(\mathrm{P})$ serta sebagian kecil logam seperti kadmium $(\mathrm{Cd})$, tembaga $(\mathrm{Cu})$, seng $(\mathrm{Zn})$, timbal $(\mathrm{Pb})$, arsen $(\mathrm{As})$, dan kromium $(\mathrm{Cr})$ [9]. Dengan demikian keberadaan partikel kayu mikro yang terdispersi dalam pupuk cair bersifat menguntungkan karena nantinya dapat digunakan sebagai sumber nutrisi bagi bibit tanaman.

\subsection{Hasil Perhitungan Fraksi Sol}

Hasil perhitungan fraksi sol yang terkandung dalam perekat UF yang digunakan sebagai bahan pengikat papan partikel menghasilkan nilai yang berbeda tergantung dari jumlah hardener yang digunakan seperti yang disajikan pada Gambar 3 berikut.

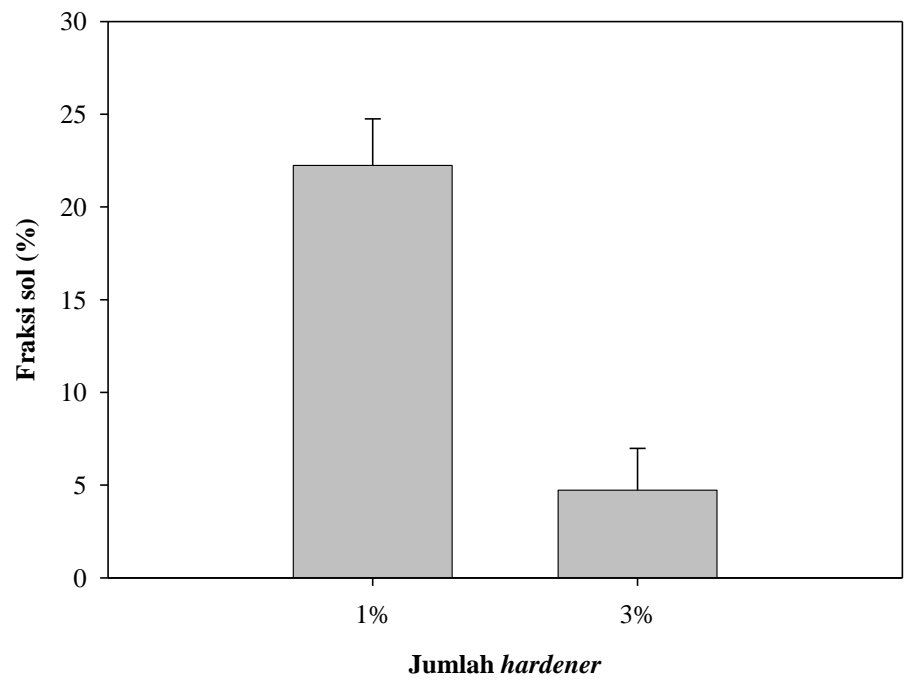


Gambar 3. Jumlah fraksi sol yang terdapat dalam perekat UF yang digunakan sebagai perekat papan partikel komersil produksi PT.Canang Indah, Medan

Perekat UF yang menggunakan hardener dengan jumlah $1 \%$ menghasilkan nilai fraksi sol yang lebih tinggi yaitu $(22.24 \pm 2.51) \%$ dibandingkan yang menggunakan hardener $3 \%$ yaitu $(4.73 \pm 2.25) \%$. Hal ini mengindikasikan penggunaan hardener akan sangat mempengaruhi ikatan silang (cross-link) perekat UF. Semakin tinggi hardener yang digunakan semakin rendah fraksi sol-nya sehingga massa yang terlarut dalam pupuk cair akan semakin rendah jika hardener yang digunakan cukup tinggi.

Pada saat ini, industri papan partikel pada umumnya menggunakan hardener tidak lebih dari 3\% sehingga fraksi sol yang terdapat dalam perekat UF masih ada. Saat papan partikel didaurulang dapat dipastikan limbah air yang diperoleh mengandung fraksi sol. Fraksi sol ini diduga merupakan urea yang tidak habis bereaksi dengan formalin dalam produksi perekat UF karena itu masih diperlukan analisis kadar N. Kandungan utama dari urea adalah nitrogen (N) di mana $\mathrm{N}$ merupakan unsur yang dibutuhkan dalam jumlah paling banyak sehingga disebut unsur hara makro primer. Umumnya $\mathrm{N}$ menyusun $1-5 \%$ dari berat tubuh tanaman. Unsur diserap oleh tanaman dalam bentuk ion amonium (NH4+) atau ion nitrat (NO3-). Sumber unsur $\mathrm{N}$ dapat diperoleh dari bahan organik, mineral tanah, maupun penambahan dari pupuk organik [10]. Lebih lanjut dijelaskan bahwa $\mathrm{N}$ berfungsi untuk menyusun asam amino (protein), asam nukleat, nukleotida, dan klorofil pada tanaman, sehingga dengan adanya $\mathrm{N}$, akan membuat tanaman lebih hijau, mempercepat pertumbuhan tanaman (tinggi, jumlah anakan, jumlah cabang) sehingga tepat untuk diaplikasikan untuk bibit, dan menambah kandungan protein hasil panen. Adapun bibit tanaman yang kekurangan unsur hara $\mathrm{N}$ akan menunjukkan gejala antara lain (1) seluruh tanaman berwarna pucat kekuningan (klorosis) akibat kekurangan klorofil, (2) pertumbuhan tanaman menjadi kerdil, jumlah anakan atau jumlah cabang sedikit, (3) perkembangan buah menjadi tidak sempurna dan seringkali masak sebelum waktunya, dan (4) pada tahap lanjut, daun menjadi kering dimulai dari daun pada bagian bawah tanaman.

Dengan demikian keberadaan fraksi sol dalam perekat UF yang digunakan sebagai pengikat papan partikel bersifat menguntungkan karena kandungan utamanya $\mathrm{N}$ yang merupakan unsur utama sebagai sumber primer nutrisi bibit tanaman.

\section{Kesimpulan}

Keberadaan mikro partikel kayu dan fraksi sol dalam pupuk cair yang diperoleh dari limbah air hasil pendaurulangan papan partikel komersial produksi PT. Canang Indah, Medan bersifat menguntungkan karena keduanya merupakan sumber nutrisi bagi bibit tanaman. Analisis lanjut kadar $\mathrm{N}$ untuk memastikan seberapa besar kandungan $\mathrm{N}$ pada pupuk cair masih perlu diteliti lebih lanjut.

\section{Ucapan Terima Kasih}

Penelitian ini dibiayai oleh DRPM Kemenristekdikti RI melalui skema PTUPT (Penelitian Terapan Unggulan Perguruan Tinggi) tahun pertama (2019-2021). Kepada Kartini Dewi Sartika Tambun disampaikan terima kasih atas pengukuran dan penghitungan fraksi sol pada penelitian ini.

\section{Referensi}

[1] Siringo-ringo, F.J. (2018) “Pengujian Siklis Papan Partikel dan Pemanfaatan Limbah Air Daur Ulangnya sebagai Pupuk", dalam Skripsi Fakultas Kehutanan, Universitas Sumatera Utara, Medan

[2] Nuryawan A, Elfiati D, Hartini K.S. (2019) "Growth and Biomass of Anthocephalus cadamba Seedlings in Response to Liquid Disposal of Particleboard's Recycling as Fertilizer", in Proceeding of International Conference on Natural Resources and Technology (Iconart 2019), In press.

[3] Nuryawan A., Singh A.P., Park BD (2015) "Swelling behaviour of cured urea-formaldehyde resin adhesives with different formaldehyde to urea mole ratios." J. Adhes /91: 677-700. 
[4] Nuryawan A., Park B.D. (2017) "Quantification of hydrolytic degradation of cured urea-formaldehyde resin adhesives using confocal laser scanning microscopy." Int.J.Adhes 74: 1-5.

[5] Achmadi, S.S. (1990) "Bahan Pengajaran Kimia Kayu”, Pusat Antar Universitas Ilmu Hayat, Institut Pertanian Bogor

[6] El-Ramady H.R., Alshaal T.A., Amer M., Domokos-Szabolcsy É., Elhawat N., Prokisch J., Fári M. (2014) "Soil Quality and Plant Nutrition.” in Sustainable Agriculture Reviews 14: Agroecology and Global Change, Ozier-Lafontaine H, Lesueur-Jannoyer M (eds), Switzerland, Springer International Publishing Switzerland

[7] Mengel, K., Kirkby, E.A., Kosegarten, H., Appel, T. (2001) “Principles of Plant Nutrition. 2nd Edition”, Berne, International Potash Institute

[8] Naylor, L.M., Schmidt, E (1986) “Agricultural use of wood ash as a fertilizer and liming material.” Tappi J. 69: 199-206.

[9] Park B.B., Yanai R.D., Sahm J.M., Ballard B.D., Abrahamson L.P. (2004) "Wood ash effects on soil solution and nutrient budgets in a willow bioenergy plantation." Water, Air, and Soil Pollution 159: 209-224.

[10] Rina D. (2015) “Manfaat unsur N, P, dan K bagi tanaman.” BPTP Kalimantan Timur (kaltim.litbang.pertanian.go.id) 